\title{
An Experimental Investigation of the Impact of Different Advertising Formats on Children's Attitudes' Towards Sports Brands
}

\author{
Ranya Ibrahim Yousif * \\ Alaa Tarek ** \\ Wael Kortam ***
}

\begin{abstract}
The study aims to investigate children's attitude towards different advertising formats including TV ads, in-movie product placement and in-game advertisements, using a web-based between subjects' experimental design among a sample of Egyptian children aged between 6 to 13 years. Children's attitude development by advertising efforts is considered under investigated in literature particularly in Arab cultures and as they are considered as powerful influencers to parents' purchase decisions, the study contributes to a better understanding of children's attitudes that will guide mangers in making wiser advertising budget allocation. The results showed that there is a significant different impact of the investigated advertising formats on children's attitude towards sports brands with higher cognitive, affective and behavioral responses resulted from the exposure to traditional video advertising compared to inmovie product placement and in-game advertisements.
\end{abstract}

Keywords: Advertising, Children Attitudes, Product Placement, Sports’ Brands

\footnotetext{
* Faculty of Management Sciences, October University for Modern Sciences and Arts (MSA), Cairo, Egypt. E-mail: ryousif@msa.edu.eg

** Faculty of Commerce, Cairo University, Egypt. E-mail: alaa_tarek2003@foc.cu.edu.eg

*** The British University in Egypt, Egypt. E-mail: wael.kortam@bue.edu.eg
} 
Received on: $2021 / 04 / 24$

Approved on: 2021/12/21

Evaluated by a double blind review system

\section{INTRODUCTION}

Marketers and researchers discovered the great importance of children as a target market which affects a variety of their families' purchase decisions, children as consumers can be beneficial in different ways from spending their own money on buying products, influencing their parents to buy what they desire in addition to their potential role as the future consumers. This raised a continuous challenge for marketers to attract, affect and to keep children loyal to their brands, which led to the increasing developments in the marketing strategies designed to target children.

The increased clutter and the saturated advertising environment with traditional advertising formats such as TV and radio along with the increasing interaction between different media and the consumers opened an opportunity for new advertising techniques to exist and these new formats make the boundaries between advertising commercial intents and the entertainment associated with advertising disappear due to the increasing complexity and creativity of the product placement formats which integrate advertising with attractive various entertaining contexts such as programs, movies and games (Verhellen et al. 2014). The new advertising strategies that grab the attention and interest of marketers, is called "creative media", which is built on using new unconventional ways of advertising executed using new formats that grab the attention of consumers and help marketers break through the clutter. However, although these formats are gaining great attention by marketers, there is a lack in the studies related to the effect of using creative media on consumers' behavioral, cognitive, and affective responses to advertising and the advertised brands (Rauwers et al. 2018).

Children are increasingly representing an attractive segment for many products among them are sports brands, where marketers of these brands are not saving any effort to create positive influence on children's attitudes toward their brands. One of the commonly used marketing activities is advertising which is developed dramatically to not only includes traditional advertisements children can see on TV but also by using new advertising formats of product placement. According to statista.com, the global spending on advertising to 
children from 2012 to 2019, showed that kids digital advertising spending in 2016 accounted for 0.6 billion U.S. dollars, while non-digital ad expenditures that year reached 3.4 billion and grown in 2019 to reach 4.2 billion U.S. dollars.

According to statista.com, the global sporting-goods market in 2018 is approaching 240 billion U.S. dollars with a forecasting that the market to reach 480 billion in 2025 with a growth rate of $10 \%$. Accordingly the context of the study is sports brands applying on one of the famous brands, which uses all advertising formats investigated in the study. The selected brand is Nike, an American multinational corporation and the one of the top companies in this industry worldwide with a brand value of 30.44 billion U.S. in 2021 Nike is considered a leading firm in terms of developing and selling sportswear for different segments including children.

The novelty of the study also stems from the fact that much of the research on the impact of advertising on consumer's brand attitude focused on adult consumers and since children cognitive abilities differ from those of the adults, it is necessary to study the brand attitude formation of children (Eshghi et al., 2017). Moreover the majority of studies about advertising and children are conducted in US and Western Europe, so the results of these studies are more applicable to these countries, hence the call for further research on children from other cultures in terms of their comprehension of advertising, the influence of advertising on their brand attitudes. The globalization and the media overlap can help companies target their customers using a global advertisement, yet this requires a clear understanding for similarities and differences in children responses to advertising and if there are country specific differences. (Vashisht \& Pillai, 2016)

This study provides theoretical and managerial implications. On the theoretical front, it draws a comparison between the traditional commonly investigated formats (i.e., TV advertising) and new advertising formats (e.g., in-game advertising and product placement in movies). It also has been applied on an uninvestigated context (i.e., sports brands) and Egyptian children. On the practical front, it provides implications for marketing communication managers of sports brands on the most effective advertising formats when targeting Egyptian children in addition to valuable managerial insights that can be beneficial for educational institutions to design creative educational materials targeted to children. The insights can also be beneficial to the governmental institutions responsible for children's rights and protection laws in Egypt on how to protect children from being exposed to inappropriate advertising content. 
The paper starts with the theoretical foundation for the research constructs including advertising, advertising formats, the concept of attitude and the effect of various advertising formats on children as per the findings of previous studies. The following sections include methodology, analysis of findings followed by the conclusion, discussion of results and the last section includes the marketing implications and suggestions for further research.

\section{LITERATURE REVIEW}

Kotler (2016, p.447) defined advertising as "any paid form of non personal presentation and promotions of ideas, goods, or services by an identified sponsor with the objective of making sales" The main benefits of advertising is to provide product related information and to grab audience attention to the advertised products, advertising is not only used to raise awareness of certain products but also to build brand image and identities (Belch \& Belch, 2017).

The significant role of advertising for marketers is mainly to grab attention to the advertised brand, to deliver information about the product which creates awareness and to develop favorable attitudes and purchase intentions towards the advertised brands all these benefits make marketers more cautious about their advertising techniques in order to succeed in today's highly competitive environment (Bamfo et al., 2019).

Children are targeted by advertising long time ago as marketers consider them not only a segment that makes independent purchases but also as influencers for a wide variety of their parent's purchase decisions. Moreover as children are exposed to various forms of advertisements and as the advertising environment becoming saturated and cluttered, advertisers are always trying to use and invent new attractive and unique way to advertise and to grab children attention to their brands (Hudders \& Cauberghe, 2018).

Advertising designed to target children raised many concerns from parents and researchers due to the fact that children are exposed to wide array of advertising formats which have an impact on children's attitude towards the advertised brand but can also result in negative effects due to promoting unhealthy products and/or unfavorable behaviors (Vanwesenbeeck et al. , 2017).

Advertising targeting children in the past decade encountered many developmentsin the new formats and media targeting children such as bloggers, social media, online advertising and the in game placements and capitalizing on the change in children use of internet and smart devices. Another important development is in the characteristics of the advertisements which 
become more fun, entertaining and engaging which make children exposed to the brand longer than before and create engagement with the brand (De Jans et al., 2019).

The difference between traditional advertising formats such as TV advertisements and the new formats such as product placement is based on how each format is used to persuade children and deliver the intended message. For the traditional media the most important factor is to deliver product related information about product quality and features and the repetition of the advertisements and use attractive execution style to create positive responses. On the other hand, new advertising formats focus mainly on the entertaining nature of theses formats such as product placement in movies or games to create higher brand exposure, engagement with the brand and to implicitly convey the intended commercial message to create favorable responses towards the placed brands (De Pauw et al., 2018).

Product placement as the most famous creative advertising format is the integration between advertising and entertainment by adding the brand in a different context have been used for more than a century and now more than $70 \%$ of movies and television programs in US are including product placement also unlike traditional media, product placement can be designed either by making the product visible in the context but not used by the character or it can be designed to make the character in the movie or the game use the product also the brand names can be explicitly acknowledged or not. Moreover product placement is extended and developed to cover new formats such as video games and also applied on social media platforms such as Facebook and YouTube (Eagle \& Dahl, 2018). Moreover product placement as a paid form of advertising has been used for several years as a method to reduce the cost of producing movies and TV programs (Hudders \& Cauberghe, 2018).

Consumers may recognize the brand mentioned or used in a movie and start formulating their cognitive and affective responses, if the brand is used by the character they like, this may send a message that this brand is of a good quality. Adding to this that exposure to product placement in movies triggers the product related association and knowledge in consumers' memory which have an influence on the formulation of brand attitudes (Gibson et al., 2014). In addition placing brands in a catchy entertaining content such as movies led to the creation of brand recall and preferences (De Jans et al., 2019).

Placing advertisements targeting children in a cartoon content garbs their attention and creates a high level of involvements with the brand which results from the involvement with the cartoon content (Blades et al., 2014). On the other hand, companies are selective 
regarding where to place their brand that the movie should be consistent with what the brand image that the company wants to achieve, a famous example for this is when Mercedes refused to place the logo of the brand in the movie Slumdog Millionnaire because they would appear in a context where unglamorous and inconsistent with the brand image (Gibson et al., 2014).

As gaming nowadays is not considered a niche activity it is becoming an activity for a wide market from different ages and genders. The old known characteristics of the game players are changing from being young males to include female players, these encouraged marketers to take this as an opportunity to use games as a format for their advertising and communication and product placement in games adds more reality to the game and lead to increasing the profits for both the gaming industry and the placed brands (Chaney et al., 2018).

Product placement in games is not only executed by placing the brand in a slot of the game but it can be developed to make the product an important part of the game and this lead to high level of interaction with the game and it is transferred to the placed brand in addition to the longer time of exposure compared to other advertising formats such ad TV as the game can be played for an average 25 minutes (Williams, 2015).

The reason for the increasing popularity of in game advertising is the decrease in the clickthrough for traditional online advertisements such as banner ads, so, advertisers take this as an opportunity to create an entertaining context for their brands that lead to increase exposure as the game can be played several times also create a connection between the player and the brand (Eagle \& Dahl, 2018).

The gamification idea is gaining huge interest to capitalize on the motivating nature of games for players to use game characteristics and formats in other nongame contexts to gain consumer's attention and engagement which may lead to high level of brand awareness and loyalty (Catalán, Martínez \& Wallace, 2019). The transformation of digital games to a mass media used by huge number of people from different ages and places along with the continuous advancements in gaming technologies made advertisers capture this opportunity to approach mass audiences from different countries effectively using digital games and the introduction of new advertising format which is advergames which is a digital game designed as a promotion and advertising tool for a specific product or brand and the game can be played on the internet or any medium the critical factor related to advergames is the 
level of entertainment achieved by playing the game as the more the player is entertained the more favorable their attitude towards the brand (Vashisht, Royne \& Sreejesh,2019).

Advergames creates high level of interactivity and connection with the advertised brand which make children like this format more that other advertising formats which lead to better advertising effect on children, advergames are considered rich area for research to understand the children's ability to recognize the advertising nature of this format and to know the expected influence on children's attitudes toward the placed brand (Vashisht et al, 2019, DeJans et al. 2019)

Attitude could be defined as the implicit brand evaluation and the children attitude toward the advertisements affect their attitude towards the placed products (Eshghi et al., 2017). Children's exposure to different advertisements leads to increased children's demand for the advertised products and this was mainly conferment using experiments that showed that children are asking for products they saw in the advertisements. On the same matter, a positive impact was detected of advertising on children's behavioral attitudes represented by brand and product category usage (Opree et al., 2014).

Different advertising formats are triggering children's thoughts and emotions and with the increasing entertaining features of advertising it is difficult for children to determine the real commercial intentions of the advertisements they are exposed to. Advertising influence can be assessed in terms of children cognitive response measured by brand recall, affective response measured by brand attitude or liking and behavioral responses measured by children purchase intentions (De Jans et al.,2019).

The importance of the study stems from the need for more updated research on advertising for children due to several reasons. First; most of the previous studies investigated few product types with the largest focus on food advertising, second; despite the increased use and importance of the new creative advertising formats, the majority of previous researches focused on traditional TV advertising. Moreover, research on other advertising formats is conducted recently and is focusing mainly on one format, which is advergame as a new advertising format (De Jans et al., 2019). On the same vein there is a lack of research studying the effect of product placement in movies as a creative advertising format on children (Hudders \& Cauberghe, 2018).

Moreover Eagle and Dahl (2018), Blades et al. (2014), Verhellen et al. (2014), and Shiying et al. (2014) stated that despite the increasing exposure of children to new commercial communication formats, the majority of the studies focused on television as one of the 
traditional formats of advertising, which raise the importance to study other advertising techniques. Therefore, this research will add contribution by first study the effect of different advertising formats, which are product placement in movies and in-game advertising, second conduct the empirical study in Egypt.

Accordingly the study addressed the following hypotheses:

H1: Exposure to television advertisement has a significant different impact on children's brand attitude than other formats;

H2: Playing a game with advertising content has a significant different impact on children's brand attitude compared to other formats;

H3: Exposure to product placement in a movie has a significant different impact on children's brand attitude than other formats.

\section{METHODOLOGY}

An experimental design is gaining considerable attention among marketing researchers; experiments enable the control of the research setting, the identification of causal association between the research variables to reach more conclusive results than the results gained by the descriptive and observational research (Tummers \& Janssens, 2014).

Due to the Covid19 pandemic, many life activities whether work, shopping, education, or entertainment shifted their activities to be performed online by all people including children. Accordingly, the researchers applied a web-based experimental design by conducting experimental studies online as a substitute for the lab experiments in which participants are exposed to and interact with the experimental materials on the internet (Webster \& Sell, 2014), moreover social sciences' researchers are increasingly using online or web based experiment to get wider access to the population both in number and geographical distribution also online experiments are low cost and faster compared to lab experiments (Palan \& Schitter, 2018, Reips, 2009).

The experimental manipulation consisted of exposure to one of three different types of advertising formats (Video advertisement - product placement in a movie - in game advertisement) using between subjects design to consider the children's limited cognitive abilities by not making them exposed to multiple treatments which is not only difficult for them but also will lead to inaccurate responses specially the brand recall as multiple 
exposures will raise the recall. So children were exposed to one of the following treatments, and answered the questionnaire.

\subsection{First experimental treatment (traditional video advertisement)}

It used a 3 minutes video advertisements for Nike called "Nike unlimited you", that was aired on TV and available online the advertisement is simple, catchy and featuring people from different ages, backgrounds including children who use Nike and achieve their goals in the sports field as shown in the Figure 1.

Figure 1. Screenshot from the video ad

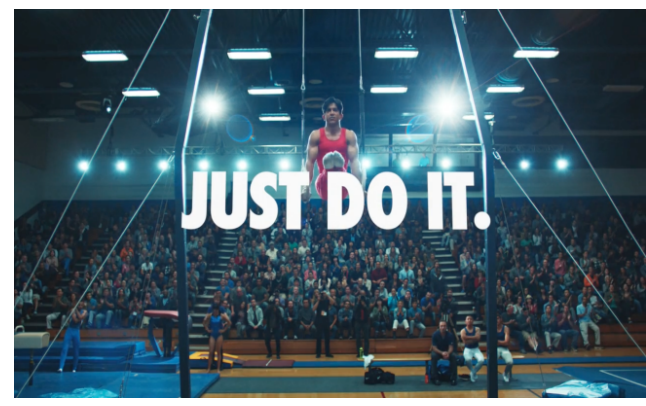

Source: YouTube

\subsection{Second experimental treatment (product placement in a movie)}

Nike is one of the brands that used product placement in many movies after searching and checking the movies suitable for children. A scene from the movie "back to the future" was selected as it was one of the top ranked product placements by Nike and the brand was used by the central character of the movie and actively placed in an attractive way as shown in the Figure 2.

Figure 2. Screenshot from the movie
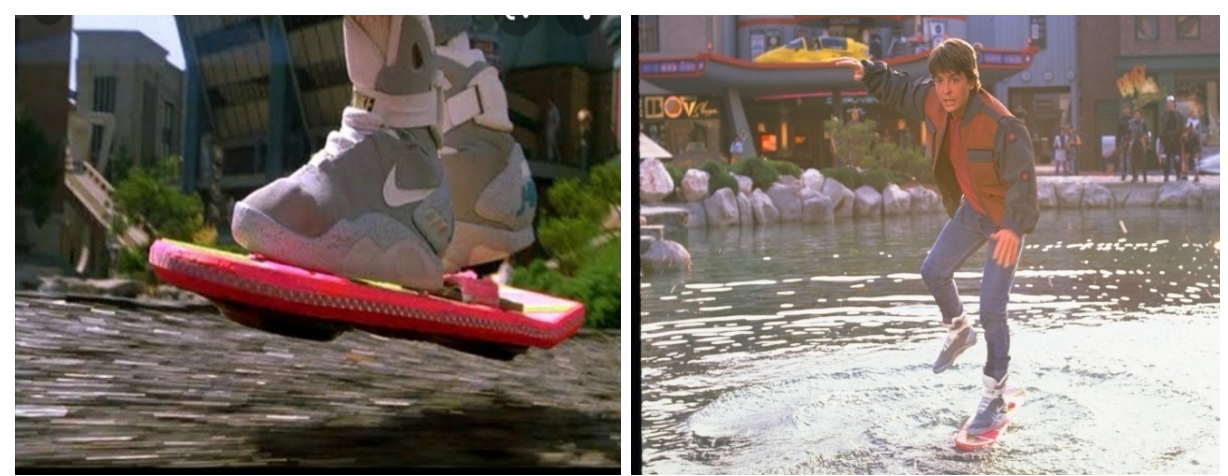

Source: YouTube 


\subsection{Third experimental treatment (in game advertising)}

A game that includes Nike advertising content in an attractive way was also wanted that is easily played by children from the age of six, in addition to its availability online and appealing to both genders. The researcher used a game called "Christiano Ronaldo Kick n'Run" and the pictures in Figure 3 show how the brand is placed in the game.

Figure 3. Screenshot from the game
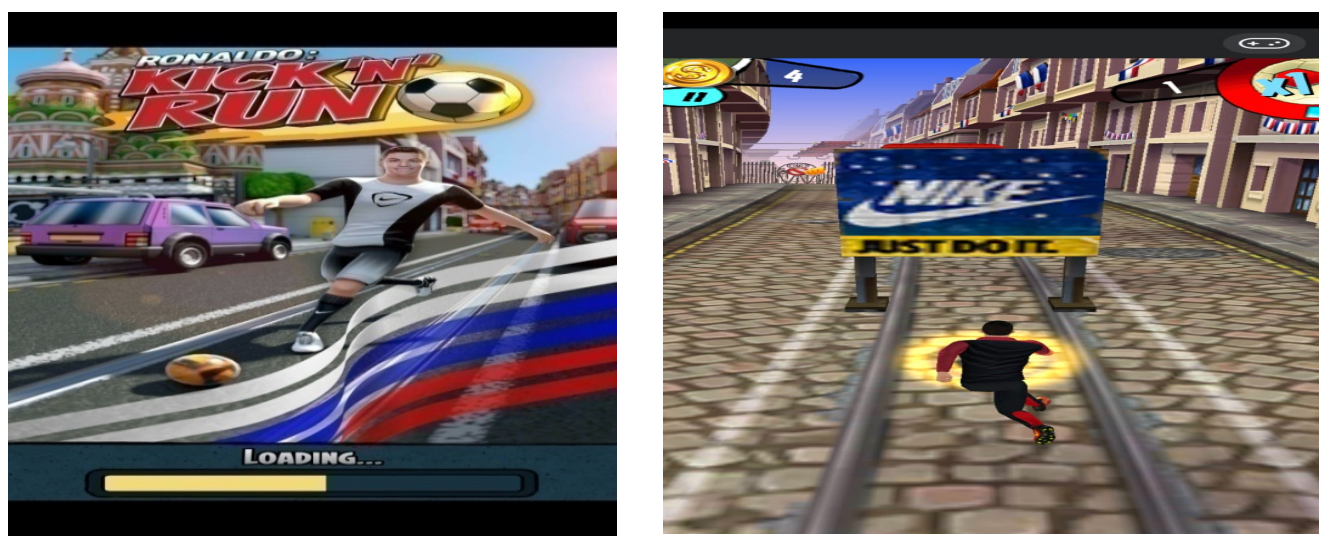

Source: Google play

The research population consists of children age from 6 to 13 all children have access to the internet through their own or their parents' technological devices such as smart phones and aware of using them and this increased as online learning was applied in all educational stages for all children due to the Covid-19 situation.

The children were approached through their parents using nonprobability snowball sampling technique by using a first group of respondents who represents the research population then ask them to give access to others with the same characteristics, so subsequent respondents are recruited based on referrals in which the researcher contacted a group of parents and ask them to refer to other parents making use of the social media and online parents' communities to seek parents approval to allow their children to participate and to ease the researcher access to other parents.

The children were randomly assigned to one of the three experimental conditions making sure that each child was exposed to only one treatment. The sample size conformed to guidelines posed by Cohen (1992) that a minimum of 20 participants per cell be used to conduct an analysis of variance, also Kraemer and Thiemann (1987) recommended to have at least 14 participants per cell for experimental design. So the study aims at conducting the 
experiment at least on 40 children per each experimental group to represent different ages. The data collection was carried out in three months. A total sample of 133 children who participated in the experiment and answered the questionnaire was reached.

\subsection{Measurements}

Questionnaire is designed to be consistent with the cognitive abilities of the children (Hudders \& Cauberghe, 2018). Thus, visual cues or faces were used as answers for the scale questions as shown in the appendix, in order to get accurate data from children and made sure that the questions are easy and the answers are understood by the children especially with the use of scale questions. It is recommended to use images or smiley faces which reflect the answers of the scale from 1 showing very sad or strongly disagree to 5 showing very happy or strongly agree (Hall et al, 2016).

Independent variables: The advertisement viewed by children participants that is manipulated to use the three advertising formats under study, which are TV advertisement, product placement in a game and in a movie.

Dependent variables: The dependent variable examined in this study is children's overall attitudes and its three components. Overall brand attitude, affective responses and behavioral responses were measured by using a 5-point smiley scale (questions from 5 to 10 in appendix 1) Cognitive component was measured by Brand recall and familiarity (questions 3 and 4 in appendix 1).

\section{RESULTS}

Each treatment includes children from various ages which enable the researcher to measure the impact of each treatment on a representative sample of children from different ages also the total number of children per treatment is roughly equal which achieved a balanced design and the ability to test the impact of all treatments without bias to any of them the three groups $(\mathrm{N}=41,44$ and 48$)$ for video advertisement, product placement in movies and in game advertising respectively. The Statistical Package for Social Sciences (SPSS) version 25 was used to conduct the data analysis.

\subsection{Children cognitive responses to different advertising formats}

Cognitive response was measured through brand recall and top of mind awareness after exposure to each type of advertising the children were asked to select the brand appeared in the ad from a list of brands and the second question is to select the first brand they think about when they consider buying sportswear. The results showed that the highest percentage 
of brand recall were for children who exposed to video advertisement (i.e. traditional advertising format) and the recall decrease for the untraditional or creative formats represented by the product placement in movies and in game advertising with slight higher percentage for product placement in movies (See Table 1).

Table 1. Children cognitive responses to different advertising formats

\begin{tabular}{|l|c|c|c|}
\hline $\begin{array}{l}\text { Cognitive } \\
\text { Responses }\end{array}$ & $\begin{array}{c}\text { First Treatment } \\
\text { (Video advertisement) }\end{array}$ & $\begin{array}{c}\text { Second treatment } \\
\text { (Product placement in a movie) }\end{array}$ & $\begin{array}{c}\text { Third treatment } \\
\text { (in game advertising })\end{array}$ \\
\hline Brand Recall & $95 \%$ & $63.6 \%$ & $62.5 \%$ \\
\hline $\begin{array}{l}\text { Top of mind } \\
\text { awareness }\end{array}$ & $63.4 \%$ & $41 \%$ & $37.5 \%$ \\
\hline
\end{tabular}

\subsection{Children affective responses to different advertising formats}

The second component of children attitude is the affective component, which measures the children's feelings towards the brand after exposure to different advertising formats.

Table 2. Children affective responses to different advertising formats

\begin{tabular}{|l|c|c|c|}
\hline \multirow{2}{*}{ Affective responses } & $\begin{array}{c}\text { First Treatment } \\
\text { (Video advertisement) }\end{array}$ & $\begin{array}{c}\text { Second treatment } \\
\text { (Product placement in a movie) }\end{array}$ & $\begin{array}{c}\text { Third treatment } \\
\text { (in game advertising })\end{array}$ \\
\cline { 2 - 4 } & \multicolumn{3}{|c|}{ Mean } \\
\hline Brand liking & 4.51 & 4.05 & 4.06 \\
\hline Nike is a Lovely brand & 4.56 & 4.07 & 4.10 \\
\hline Nike is a modern brand & 4.22 & 3.77 & 4.08 \\
\hline Grand mean & $\mathbf{4 . 4 3}$ & $\mathbf{3 . 9 6}$ & $\mathbf{4 . 0 8 3}$ \\
\hline
\end{tabular}

The affective response was measured by asking children about to what extent they like Nike, see it as a lovely and modern brand using a smiley faces scale from 1 to 5 and table shows the results according to the mean. The majority of children have positive emotional responses after the exposure to all three types of advertisements moreover the highest positive emotions resulted from exposure to video advertisements and playing a game with an advertising content with a grand mean of 4.43 and 4.08 respectively (See Table 2).

\subsection{Children Behavioral responses to different advertising formats}

The third component of children attitude is the behavioral component, which measures the children's behavioral intentions towards the brand after exposure to different advertising formats. 
Table 3. Children behavioral responses to different advertising formats

\begin{tabular}{|l|c|c|c|}
\hline \multirow{2}{*}{ Behavioral responses } & $\begin{array}{c}\text { First Treatment } \\
\text { (Video advertisement) }\end{array}$ & $\begin{array}{c}\text { Second treatment } \\
\text { (Product placement in a movie) }\end{array}$ & $\begin{array}{c}\text { Third treatment } \\
\text { (in game advertising })\end{array}$ \\
\cline { 2 - 4 } & \multicolumn{3}{|c|}{ Mean } \\
\hline $\begin{array}{l}\text { Brand purchase } \\
\text { intention }\end{array}$ & 4.44 & 3.89 & 4.13 \\
\hline $\begin{array}{l}\text { Purchase request from } \\
\text { parents }\end{array}$ & 4.02 & 3.68 & 3.83 \\
\hline Grand mean & $\mathbf{4 . 2 3}$ & $\mathbf{3 . 7 8}$ & $\mathbf{3 . 9 7}$ \\
\hline
\end{tabular}

The behavioral response of the children was measured by asking them if they want to buy or ask their parents to buy Nike products in the future using a smiley faces scale from 1 "absolutely not" to 5 "absolutely yes" and as shown in table according to the mean children have positive behavioral responses and intentions after the exposure to all three types of advertisements moreover the highest behavioral responses resulted from exposure to video advertisements and playing a game with an advertising content with a grand mean of 4.23 and 3.97 (See Table 3).

\subsection{Children's overall brand attitudes after exposure to different advertising formats}

The researcher measured the children overall brand attitude after exposure of each experimental treatment to know their attitude towards the brand after the exposure to each type of advertising.

Table 4. Children overall brand attitude

\begin{tabular}{|l|c|c|c|}
\hline \multirow{2}{*}{ Brand attitude } & $\begin{array}{c}\text { First Treatment } \\
\text { (Video advertisement) }\end{array}$ & $\begin{array}{c}\text { Second treatment } \\
\text { (Product placement in a movie) }\end{array}$ & $\begin{array}{c}\text { Third treatment } \\
\text { (in game advertising ) }\end{array}$ \\
\cline { 2 - 4 } & \multicolumn{3}{|c|}{ Mean } \\
\hline $\begin{array}{l}\text { Stars given to Nike } \\
\text { (from one to three stars) }\end{array}$ & 2.85 & 2.59 & 2.60 \\
\hline Very good/very bad & 4.73 & 4.25 & 4.40 \\
\hline Favorable/ unfavorable & 4.37 & 4.25 & 4.23 \\
\hline
\end{tabular}

Table 4 showed children overall attitude towards Nike, the researcher used three questions the first is asking the children how many stars they give to Nike from 1 to three and as shown by the mean the majority of children gave the brand 3 stars, the second question is using smiley faces scale from 1 very bad to 5 very good and the last question scale from 1 extremely unfavorable to 5 extremely favorable and according to the mean the majority of children hold positive attitude towards the brand with higher positive attitudes after exposure to video advertisements compared to other creative formats. 


\subsection{Testing the significant different effect of the three advertising formats on children's brand recall as a measure of cognitive response}

ANOVA analysis of variance was used to compare between independent groups.

Table 5 showed the comparison between the groups of children who watched a video advertisement, watched part of a movie with product placement and the third group who played a game with an advertising content. According to the sig. there is a statistically significant difference in brand recall between the video advertising and product placement in a movie as p-value is 0.001 , a significant difference between brand recall after watching a video advertising versus in game advertising with p-value of 0.000 . Moreover there is no significant difference in brand recall between product placement in a movie and in game placement with a p-value above 0.05 which is 0.99 .

Table 5. The significant different effect of the three advertising formats on children's brand recal

\begin{tabular}{|c|c|c|c|c|}
\hline \multicolumn{5}{|c|}{ Multiple Comparisons } \\
\hline \multicolumn{5}{|c|}{ Dependent Variable: Brand Recall } \\
\hline \multicolumn{5}{|l|}{ Games-Howell } \\
\hline Treatments & $\begin{array}{l}(\mathrm{J}) \text { What did you } \\
\text { watch/experience? }\end{array}$ & Mean Difference (I-J) & Std. Error & Sig. \\
\hline \multirow{3}{*}{$\begin{array}{l}\text { Watching a video } \\
\text { advertisement }\end{array}$} & $\begin{array}{l}\text { Watching a part of a } \\
\text { movie }\end{array}$ & $-.315^{*}$ & .081 & .001 \\
\hline & & & & \\
\hline & Playing a game & $-.326^{*}$ & .078 & .000 \\
\hline \multirow[t]{2}{*}{$\begin{array}{l}\text { Product placement in a } \\
\text { movie }\end{array}$} & $\begin{array}{l}\text { Watching a video } \\
\text { advertisement }\end{array}$ & $.315^{*}$ & .081 & .001 \\
\hline & Playing a game & -.011 & .102 & .993 \\
\hline \multirow[t]{2}{*}{ In game advertising } & $\begin{array}{l}\text { Watching a video } \\
\text { advertisement }\end{array}$ & $.326^{*}$ & .078 & .000 \\
\hline & $\begin{array}{l}\text { Watching a part of a } \\
\text { movie }\end{array}$ & .011 & .102 & .993 \\
\hline
\end{tabular}

\subsection{Testing the significant different effect of the three advertising formats on children's brand liking as a measure of the affective response}

Table 6 showed the comparison between the groups of children who watched a video 
advertisement, watched part of a movie with product placement and the third group who played a game with an advertising content. And according to the sig. there is a statistically significant difference in brand liking between the video advertising and product placement in a movie as p-value is 0.04 , a significant difference between brand liking after watching video advertising versus in game advertising with $p$-value of 0.04 . Moreover no significant difference in brand liking after exposure to product placement in a movie versus in game placement with a p-value above 0.05 which is 0.997 .

Table 6. The significant different effect of the three advertising formats on children's brand liking

\begin{tabular}{|c|c|c|c|c|}
\hline \multicolumn{5}{|c|}{ Multiple Comparisons } \\
\hline \multicolumn{5}{|c|}{ Dependent Variable: Nike brand liking } \\
\hline \multicolumn{5}{|c|}{ Games-Howell } \\
\hline Treatments & $\begin{array}{l}(\mathrm{J}) \text { what did you } \\
\text { watch/experience? }\end{array}$ & $\begin{array}{c}\text { Mean } \\
\text { Difference }\end{array}$ & $\begin{array}{l}\text { Std. } \\
\text { Error }\end{array}$ & Sig. \\
\hline \multirow{2}{*}{$\begin{array}{l}\text { Watching a video } \\
\text { advertisement }\end{array}$} & $\begin{array}{l}\text { Watching a part of a } \\
\text { movie }\end{array}$ & $.467^{*}$ & .187 & .040 \\
\hline & Playing a game & $.450^{*}$ & .182 & .041 \\
\hline \multirow[t]{2}{*}{$\begin{array}{l}\text { Product placement in a } \\
\text { movie }\end{array}$} & $\begin{array}{l}\text { Watching a video } \\
\text { advertisement }\end{array}$ & $-.467^{*}$ & .187 & .040 \\
\hline & Playing a game & -.017 & .225 & .997 \\
\hline \multirow[t]{2}{*}{ In game advertising } & $\begin{array}{l}\text { Watching a video } \\
\text { advertisement }\end{array}$ & $-.450^{*}$ & .182 & .041 \\
\hline & $\begin{array}{l}\text { Watching a part of a } \\
\text { movie }\end{array}$ & .017 & .225 & .997 \\
\hline
\end{tabular}

\subsection{Testing the significant different effect of the three advertising formats on children's behavioral response}

Table 7 shows that there are no significant differences in children's behavioral intensions based on the different advertising formats as Sig. is more than 0.05 except for slight difference between watching a video advertising versus product placement in a movie with Sig. of 0.049 . 
Table 7. The significant different effect of the three advertising formats on children's behavioral response

\begin{tabular}{|c|c|c|c|c|}
\hline \multicolumn{5}{|c|}{ Multiple Comparisons } \\
\hline \multicolumn{5}{|c|}{ Dependent Variable: behavioral response } \\
\hline \multicolumn{5}{|l|}{ Games-Howell } \\
\hline Treatments & $\begin{array}{l}(\mathrm{J}) \text { What did you } \\
\text { watch/experience? }\end{array}$ & $\begin{array}{c}\text { Mean Difference } \\
(\mathrm{I}-\mathrm{J})\end{array}$ & Std. Error & Sig. \\
\hline \multirow{2}{*}{$\begin{array}{l}\text { Watching a video } \\
\text { advertisement }\end{array}$} & Watching a part of a movie & $.44762^{*}$ & .18680 & .049 \\
\hline & Playing a game & .25254 & .18511 & .364 \\
\hline \multirow[t]{2}{*}{ Product placement in a movie } & $\begin{array}{l}\text { Watching a video } \\
\text { advertisement }\end{array}$ & $-.44762^{*}$ & .18680 & .049 \\
\hline & Playing a game & -.19508 & .21714 & .643 \\
\hline \multirow[t]{2}{*}{ In game advertising } & $\begin{array}{l}\text { Watching a video } \\
\text { advertisement }\end{array}$ & -.25254 & .18511 & .364 \\
\hline & Watching a part of a movie & .19508 & .21714 & .643 \\
\hline
\end{tabular}

\subsection{Testing the significant different effect of the three advertising formats on children's overall brand attitude}

Table 8 showed the comparison between the groups of children after exposure to different advertising formats based on the overall attitudes towards Nike and according to the Sig. there is a significant difference between the attitude of the children who were exposed to a video advertising and those who watch a part of a movie with product placement with a Sig. of 0.01 . There is also a weak difference between the attitude of the children who were exposed to a video advertising and those who play a game with an advertising content with a Sig. of 0.05 . on the other hand no significant difference were detected between the attitude of the children who were exposed to a part of a movie with product placement and who play a game with an advertising contents with a Sig. 0.723 . 
Table 8. The significant different effect of the three advertising formats on children's overall attitude towards the brand

\begin{tabular}{|c|c|c|c|c|}
\hline \multicolumn{5}{|c|}{ Multiple Comparisons } \\
\hline \multicolumn{5}{|c|}{ Dependent Variable: overall attitude towards Nike } \\
\hline \multicolumn{5}{|c|}{ Games-Howell } \\
\hline Treatments & $\begin{array}{l}\text { (J) what did you } \\
\text { watch/experience? }\end{array}$ & $\begin{array}{c}\text { Mean Difference } \\
\text { (I-J) }\end{array}$ & Std. Error & Sig. \\
\hline \multirow{2}{*}{$\begin{array}{l}\text { Watching a video } \\
\text { advertisement }\end{array}$} & Watching a part of a movie & $.482^{*}$ & .159 & .010 \\
\hline & Playing a game & .336 & .144 & .057 \\
\hline \multirow[t]{2}{*}{ Product placement in a movie } & $\begin{array}{l}\text { Watching a video } \\
\text { advertisement }\end{array}$ & $-.482^{*}$ & .159 & .010 \\
\hline & Playing a game & -.146 & .190 & .723 \\
\hline \multirow[t]{2}{*}{ In game advertising } & $\begin{array}{l}\text { Watching a video } \\
\text { advertisement }\end{array}$ & -.336 & .144 & .057 \\
\hline & Watching a part of a movie & .146 & .190 & .723 \\
\hline
\end{tabular}

\section{DISCUSSION}

The results of the study are aligned with Waiguny and Terlutter (2011) who drew a comparison between using television advertising and placing a product in games and found that TV creates more brand recall. Moreover, this can be justified by Vanwesenbeeck et al. (2017) as children allocate more of their cognitive processing abilities to understand TV advertisements compared to other formats because advertising on TV are separated from the context using advertisements' spots. However, in other formats such as product placement children are already allocated the greatest portion of their cognitive abilities to the context in which the advertisement is placed in leaving small amount to identify and process the commercial message. On the same vein Staiano and Calvert (2014) highlighted that advergames may create lower levels of brand recall compared with using traditional advertising formats due to the nature of the advergame that requires children to allocate considerable amount of their cognitive skills and memory to the game itself.

The results are also aligned with DePauw et al. (2018) that children have positive perception and evaluation of the new advertising formats such as product placement in movies and games because of the entertaining, cool and unique nature of these formats and the fact that the advertisements are part of a fun experience and content. On the other hand Results are 
inconsistent with (Hudders et al., 2016) who concluded that using the new untraditional advertising formats creates favorable attitudes and purchase intentions for the advertised brands more than traditional ways such as TV advertisements especially among children.

The results are also aligned with Eagle and Dahl (2018) that different advertising formats have different effect on consumers highlighting that the format of placing products in movies and the ability of the consumers to see the product on large cinema screens lead to higher brand recognition. And this is interpreted according to De Pauwet (2018) that the different advertising formats are triggering children's thoughts and emotions and with the increasing entertaining features of advertising it becomes difficult for children to determine the real commercial intentions of the advertisements they are exposed to.

\section{CONCLUSION}

The results revealed that the investigated advertising formats led to high levels of brand recall, but even though advertisers believe branded entertainment using creative media advertising is more captivating for customers the results found that the highest level of brand recall was detected from children exposed to video advertisement (i.e. traditional advertising format) and the recall decreased for the untraditional or creative formats represented by the product placement in movies and in game advertising. On the other hand there is a significant difference in brand liking resulted by exposure to video advertising compared to other creative formats (product placement in a movie and in game advertising) moreover no significant difference in cognitive and affective responses were detected between creative advertising formats. As for the behavioral response children have positive behavioral responses after the exposure to all three advertising formats and, there are no significant differences in children's behavioral intensions based on the different advertising formats. Finally a significant difference in brand overall attitude was detected between the video advertising compared to other creative formats.

\subsection{Implications}

The study findings provides the following managerial implications:

First for the marketing communication managers for sports brands, to reduce the budget allocated to traditional media formats such as TV advertising, and give the highest emphasis to online advertising. As traditional video advertising led to higher brand recall so this type of advertising is recommended to be used when brand awareness and recall are the 
objectives. As product placement in movie led to positive brand attitude, so marketers can increase the use of this format and focus on the type of movies that attracts children which are not only cartoon or animation movies, as children nowadays are more attracted to adventure, action and superheroes' movies and are paying attention to the actors and what they wear and like to imitate them. Design simple advergames for the brand not only using product placement in the game to create more children interaction with the brand itself and make the game easy to give chance for children to allocate some of their cognitive abilities to process the brand related elements. As for in game advertising sports brands need to be placed in different types of games as the FIFA game is not now the most preferred by children specially girls in addition to using active placement by making the brand an important part of the game not only passive in game advertising.

For the governmental institutions responsible for children's rights and protection laws in Egypt, continuous protection's regulations should be developed to protect children from being exposed to inappropriate content for their age and creating social marketing awareness campaigns for both children and their parents about the beneficial use of internet to develop important skills and knowledge for children not only for entertainment.

To Educational institutions Egypt, new creative ways can be implemented for children to create positive attitudes towards education such as using games to educate children so they can learn and practice mathematics for example by participating in an online game and this will make them repeatedly try to learn in order to win the game. In addition to conduct entertainment online activities for children to make them improve their skills and learn by experience such as competitions, online educational communities to engage and provide them with beneficial content.

\subsection{Areas for further research}

Future research can investigate the effect of the characteristics of the game in which the brand is placed as (Vashisht, et al, 2019) explained some characteristics of the game, which can affect consumers' interaction, and perception of the advergames such as brand prominence or the extent to which the brand is placed as a central or peripheral stimulus in the game. The same research can be applied on older audience not children as (De Jans et al., 2019) differentiated between children and adults in terms of the development of their cognitive skills arguing that children have lower abilities to distinguish and critically evaluate the advertising commercial intent. Other study can investigate the effect of single versus multiple exposures to the advertisements as per the findings of the American 
psychological association which indicated a strong impact of advertising on children's preferences of certain products and this impact ranges from general preference when children are exposed once to an advertisements to a strong product or brand preference that occurs after multiple exposures to advertisements.

\section{REFERENCES}

Bamfo, B. A., Kraa, J. J., Asabere, P., \& Atarah, B. A. (2019). Effect of television adverts on children's purchase behavior: Evidence from Ghana. Cogent Business \& Management, 6(1), 1614740 .

Belch, G. E., \& Belch, M. A. (2017). Advertising and promotion: An integrated marketing communications perspective 6th. New York: NY: McGraw-Hill.

Blades, M., Oates, C., Blumberg, F., \& Gunter, B. (Eds.). (2014). Advertising to children: New directions, new media. Springer.

Catalán, S., Martínez, E., \& Wallace, E. (2019). Analyzing mobile advergaming effectiveness: the role of flow, game repetition and brand familiarity. Journal of Product \& Brand Management, 502-514.

Chaney, I., Hosany, S., Wu, M. S. S., Chen, C. H. S., \& Nguyen, B. (2018). Size does matter: Effects of in-game advertising stimuli on brand recall and brand recognition. Computers in Human Behavior, 86, 311-318.

Charness, G., Gneezy, U., \& Kuhn, M. A. (2012). Experimental methods: Between-subject and within-subject design. Journal of Economic Behavior \& Organization, 81(1), 1-8.

Cohen, J. (1988). Statistical Power Analysis for the Behavioral Sciences, Academic Press, New York, $2^{\text {nd }}$ edn.

De Jans, S., Van de Sompel, D., Hudders, L., \& Cauberghe, V. (2019). Advertising targeting young children: an overview of 10 years of research (2006-2016). International Journal of Advertising, 38(2), 173-206.

De Pauw, P., De Wolf, R., Hudders, L., \& Cauberghe, V. (2018). From persuasive messages to tactics: Exploring children's knowledge and judgement of new advertising formats. New Media \& Society, 20(7), 2604-2628.

De Pauw, P., Hudders, L., \& Cauberghe, V. (2018). Disclosing brand placement to young children. International Journal of Advertising, 37(4), 508-525.

Eagle, L., \& Dahl, S. (2018). Product placement in old and new media: examining the evidence for concern. Journal of Business Ethics, 147(3), 605-618.

Eshghi, A., Sarkar, J.G., Sarkar, A. (2017). Impact of online advertising on adolescent's brand attitudes, Marketing Intelligence \& Planning, 35(6), 706-723.

Gibson, B., Redker, C., \& Zimmerman, I. (2014). Conscious and nonconscious effects of product placement: Brand recall and active persuasion knowledge affect brand attitudes and brand self-identification differently. Psychology of Popular Media Culture, 3(1),

Hall, L., Hume, C., \&Tazzyman, S. (2016, June). Five degrees of happiness: Effective smiley face likert scales for evaluating with children. In Proceedings of the The 15th International Conference on Interaction Design and Children (pp. 311-321).

Hudders, L., \& Cauberghe, V. (2018). The mediating role of advertising literacy and the 
moderating influence of parental mediation on how children of different ages react to brand placements. Journal of Consumer Behaviour, 17(2), 197-210.

Hudders, L., Cauberghe, V., Panic, K., \& De Vos, W. (2016). Children's Advertising Literacy for New Advertising Formats: The Mediating Impact of Advertising Literacy on the (Un) Intended Effects of Advergames and Advertising Funded Programs. In Advances in Advertising Research (Vol. VI), 241-252, Springer Gabler, Wiesbaden.

Kotler, P. \& Armstrong G. (2016).Principles of Marketing 6th edition, Pearson Education. Kraemer, H. C., and Thiemann, S. (1987). How many subjects? Statistical power analysis in research. Newbury Park, CA: Sage, 38-53.

Opree, S. J., Buijzen, M., van Reijmersdal, E. A., \& Valkenburg, P. M. (2014). Children's advertising exposure, advertised product desire, and materialism: A longitudinal study. Communication Research, 41(5), 717-735

Palan, S., \& Schitter, C. (2018).Prolific.ac —A subject pool for online experiments. Journal of Behavioral and Experimental Finance, 17, 22-27.

Rauwers, F., Remmelswaal, P., Fransen, M. L., Dahlén, M., \& Van Noort, G. (2018). The impact of creative media advertising on consumer responses: two field experiments. International Journal of Advertising, 37(5), 749-768.

Reips, U. D. (2009, February). Internet experiments: Methods, guidelines, metadata. In Human Vision and Electronic Imaging XIV (Vol. 7240, p. 724008). International Society for Optics and Photonics.

Staiano, A. E., \& Calvert, S. L. (2014).The Influence of Advergames on Children' Consumer Choices and Behavior. In Advertising to Children (pp. 218-238). Palgrave Macmillan, London.

Statista (2021). Brand value of the sports company Nike worldwide from 2016 to 2021. https://www.statista.com/statistics/632210/nike-brand-value/

Tummers, J., \& Janssens, K. (2014). Experiments with crossed effects in marketingcommunication research: What do the experimental settings tell us? In Paradigm Shifts and Interactions, 43rd Annual EMAC Conference.

Vanwesenbeeck, I., Opree, S. J., \& Smits, T. (2017). Can Disclosures Aid Children's Recognition of TV and Website Advertising?.In Advances in Advertising Research VIII (pp. 45-57). Springer Gabler, Wiesbaden.

Vashisht, D., Royne, M. B., \&Sreejesh, S. (2019). What we know and need to know about the gamification of advertising. European Journal of Marketing, 607-634.

Vashisht, D., \& Pillai, S. S. (2016). Are they really persuaded with the brand embedded in the game? Journal of Research in Interactive Marketing, 249-264.

Verhellen, Y., Oates, C., De Pelsmacker, P., \& Dens, N. (2014). Children's responses to traditional versus hybrid advertising formats: The moderating role of persuasion knowledge. Journal of Consumer Policy, 37(2), 235-255.

Waiguny, M., \& Terlutter, R. (2010).Entertainment in Advergames and its Influence on Brand-Related Outcomes for Children. In Advances in Advertising Research, Vol. 1, pp. 171186.

Webster, M., \& Sell, J. (Eds.).(2014). Laboratory experiments in the social sciences. Elsevier Williams J.M. (2015). Advergames as a developmental challenge to children's processing of persuasive messages, Ph.D. Dissertation (Accessed from ProQuest Database), Fordham University, New York, USA. 


\section{Appendix 1. Questionnaire}

Q1. What did you experience?

1- Watching a video advertisement

2- Watching a part of a movie

3- Playing a game

Q2. Did you like what you saw?

Don't like it at all 1 2 3

Like it very much 5

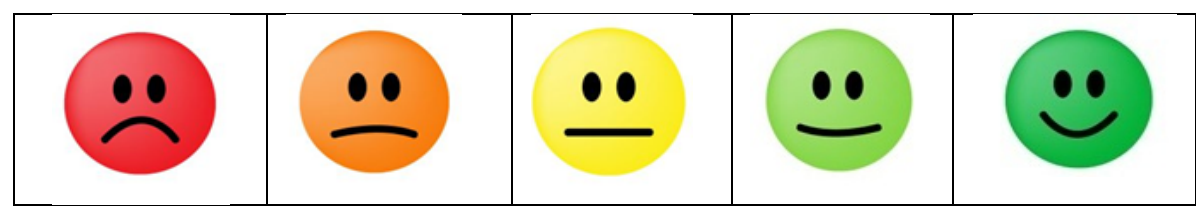

Q3. Which oneof these brands appeared in what you saw/played?

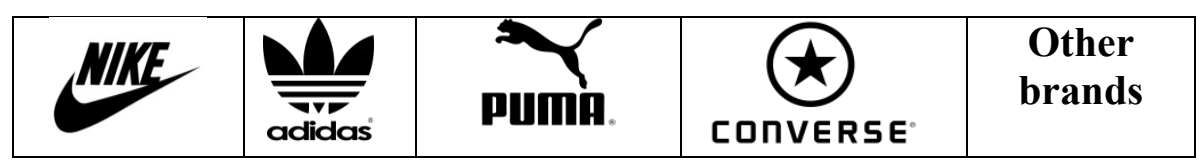

Q4. Which brand first comes to your mind when you think about sports wear?

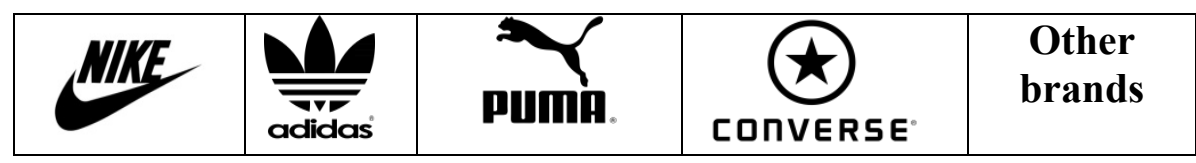

Q5. How much do you like Nike?

Don't like it at all 1 2 3 4

Like it very much 5

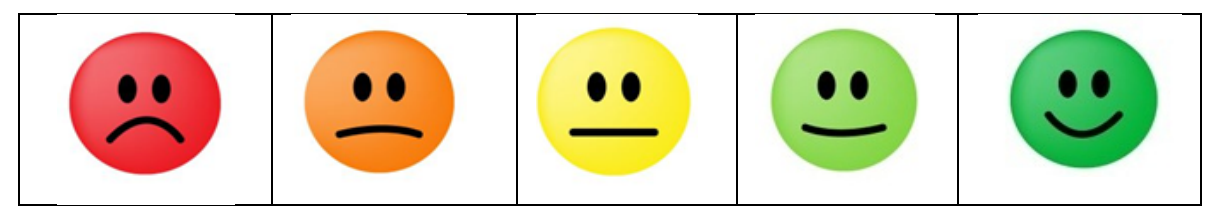


Q6. Nike is...

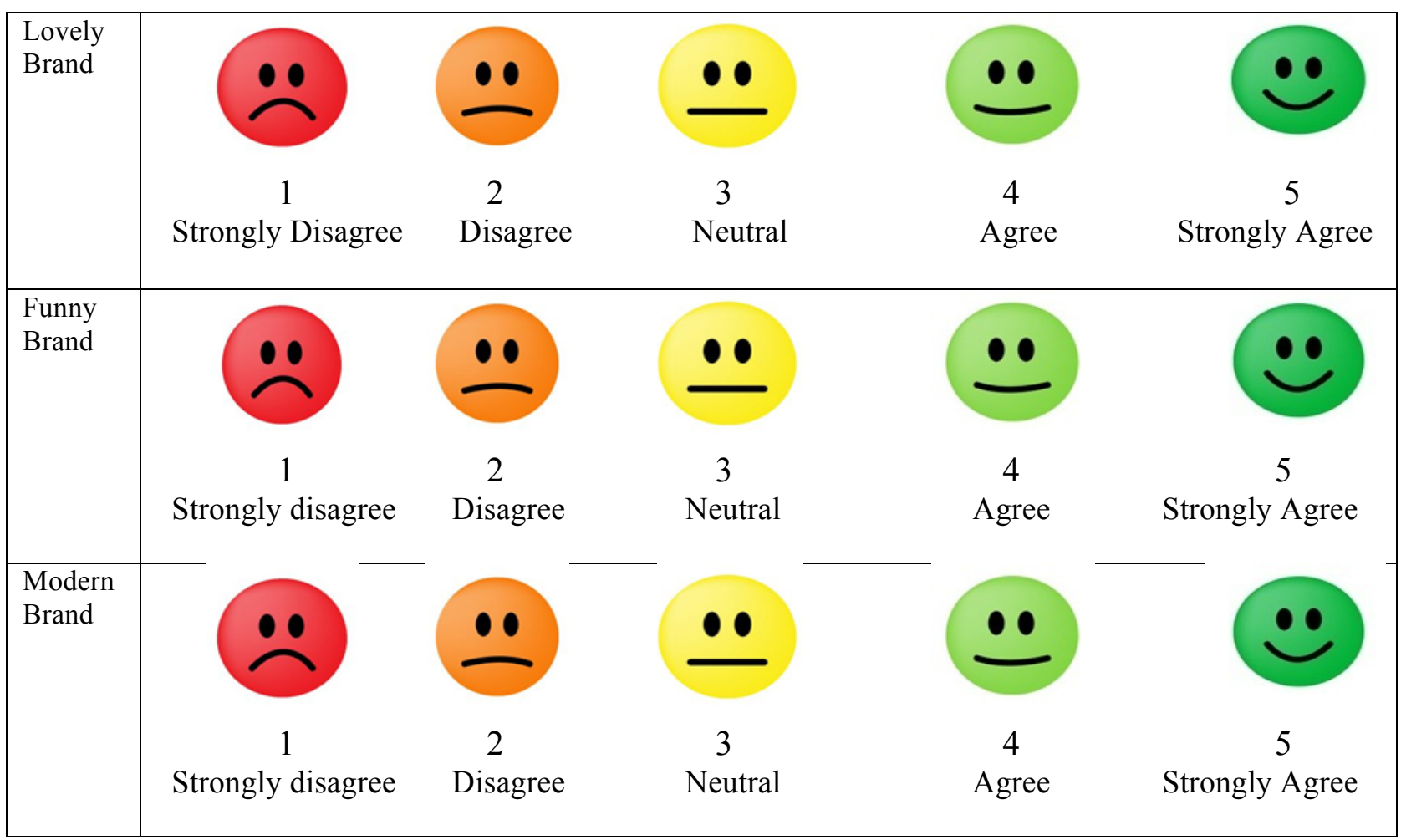

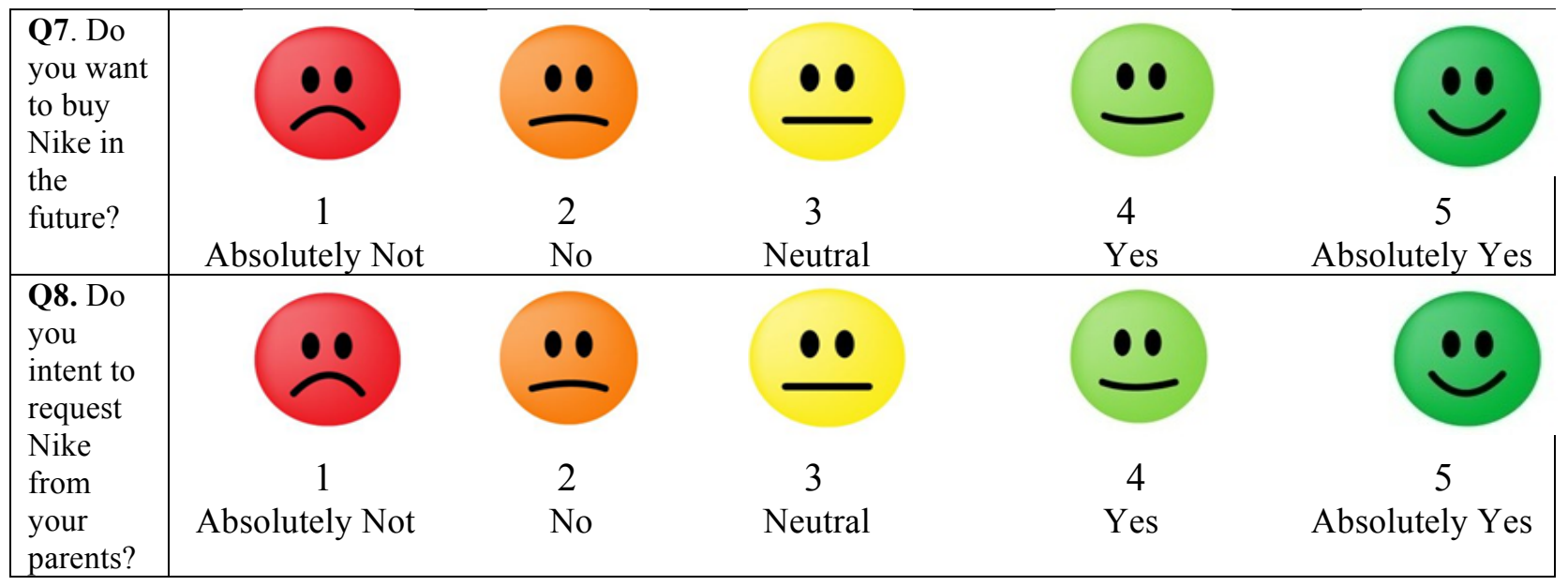

Q9. How many stars do you give Nike?

$$
\text { گr }
$$


Q10. Nike Brand is...

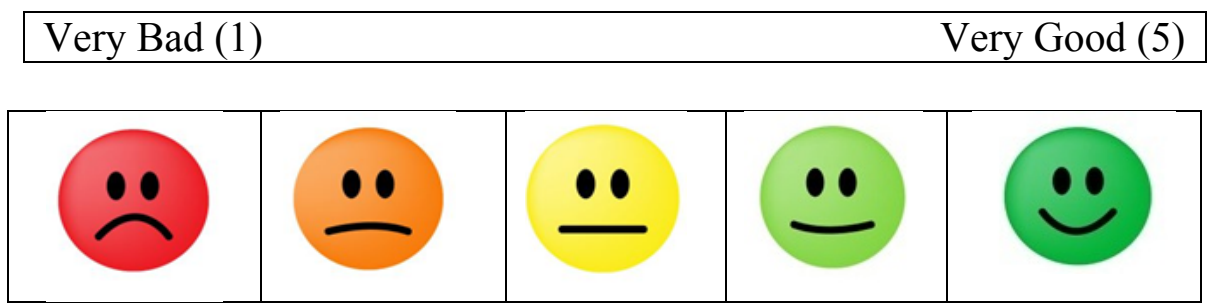

\begin{tabular}{|ll}
\hline Unfavorable (1) & Favorable (5) \\
\hline
\end{tabular}

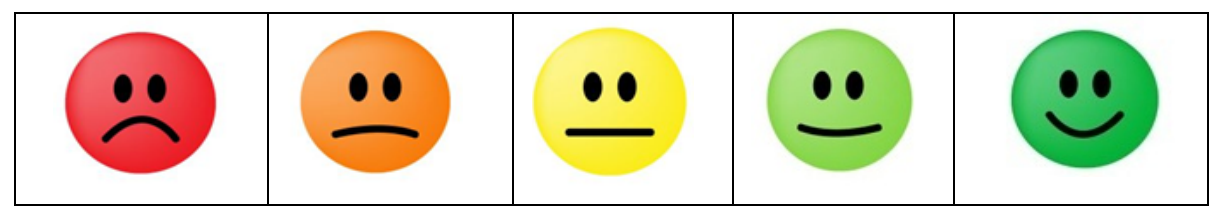

\section{How to cite this article:}

Yousif, R. I; Tarek, A.; \& Kortam, W. (2021). An Experimental Investigation of the Impact of Different Advertising Formats on Children's Attitudes' Towards Sports Brands. International Journal of Marketing, Communication and New Media, Vol. 9, No 17, 48-71. 